\title{
Ice-age steppe vegetation in east Beringia
}

Tiny plant fossils indicate how this frozen region once sustained huge herds of mammals.

T he landmass known as Beringia is an extensive region that existed during the Pleistocene epoch and included the land bridge between present-day Siberia and Alaska, now submerged beneath the Bering Strait. It must have been covered with vegetation even during the coldest part of the most recent ice age (some 24,000 years ago) because it supported large populations of woolly mammoth, horses, bison and other mammals during a time of extensive Northern Hemisphere glaciation, although the nature of this vegetation has not been determined ${ }^{1-3}$. Here we report the discovery of macrofossils of prairie sage (Artemisia frigida), bunch-grasses and forbs that are representative of ice-age steppe vegetation associated with Pleistocene mammals in eastern Beringia. This vegetation was unlike that found in modern Arctic tundra, which can sustain relatively few mammals, but was instead a productive ecosystem of dry grassland that resembled extant subarctic steppe communities ${ }^{4,5}$.

Spectra of fossil pollens indicate that there was a high proportion of sage (Artemisia) and grass (Poaceae) in eastern Beringia $^{6}$, suggesting that this region might have contained an arid but productive, grass-dominated ecosystem. This system, called a 'mammoth-steppe", would have sustained mammalian herds all year round. The fossil pollens have alternatively been interpreted as representing a discontinuous herb-tundra ecosystem ${ }^{3}$. Limited taxonomic resolution of dominant pollen types precludes the clear differentiation of steppe from tundra vegetation and calls for more conclusive evidence ${ }^{1,7,8}$.

We analysed plant macrofossils (Fig. 1) from three late-Pleistocene sites in Yukon Territory, Canada. These were recovered from a rodent nest, radiocarbon-dated at about 24,000 years before present (yr BP), in Quartz Creek in western central Yukon ${ }^{5}$; from the stomach contents of a permafrostfrozen carcass of an extinct horse (Equus lambei, 26,280 $\pm 210 \mathrm{yr} \mathrm{BP}^{9}$; from an alluvial peat $(25,700 \pm 400 \mathrm{yr} \mathrm{BP})$ associated with woolly-mammoth remains found in Last Chance Creek, also in western central Yukon; and from a 3.5-metre-thick sediment sequence $(18,800-16,400 \mathrm{yr} \mathrm{BP})$, from Bluefish River exposure in northern Yukon. These assemblages reflect the local vegetation that would have been associated with fossil mammals in easternmost Beringia.

Our macrofossils are dominated by sage, bunch-grasses and grass-like plants, and include other vegetation that would have flourished in cold, dry steppe conditions.
Figure 1 Late-Pleistocene plant macrofossils from Yukon Territory, Canada. a, Sage (Artemisia) flower; b, mustard (Draba) seed; c, wild-rye grass (Elymus) seed; d, prairie sage (Artemisia frigida) leaf. Fossils were identified by comparison with herbarium specimens. Scale bars: $\mathbf{a}, \mathbf{b}, 0.1 \mathrm{~mm}$; c, $1 \mathrm{~mm}$; d, $2 \mathrm{~mm}$
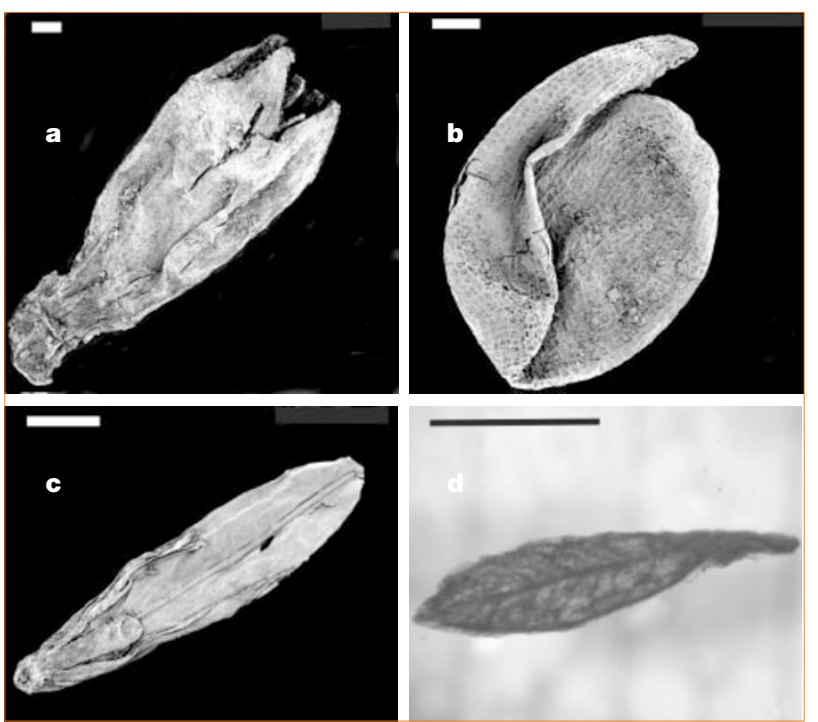

Abundant sage (Artemisia frigida) leaves, flowers from Artemisia sp., and seeds of bluegrass (Poa), wild-rye grass (Elymus), sedge (Carex) and rushes (Juncus/Luzula) support this interpretation. Seeds of cinquefoil (Potentilla), goosefoot (Chenopodium), buttercup (Ranunculus), mustard (Draba), poppy (Papaver), fairy-candelabra (Androsace septentrionalis), chickweed (Cerastium) and campion (Silene) are indicative of diverse forbs growing on dry, open, disturbed ground, possibly among predominantly aridsteppe vegetation ${ }^{4,5}$. Such an assemblage has no modern analogue in Arctic tundra ${ }^{3}$. Local habitat diversity is indicated by sedge and moss peat from deposits that were formed in low-lying wet areas.

The absence of sage and bunch-grass macrofossils from central Beringia suggests that steppe flora did not cover all of Beringia $^{1,7,8}$. Instead, it is likely that local ecological mosaics existed, on the basis of evidence of wet tundra in poorly drained lowlands ${ }^{7}$ and of dry, herb-and-sedge (Kobresia sp.) upland tundra that developed under the influence of loess deposition ${ }^{8}$. Macrofossil information indicates that local factors, including soil moisture, loess deposition, slope and altitude, were important in determining regional Beringian vegetation ${ }^{1}$. Comparison of the features of these macrofossils indicates that there were likely to have been marked ecological differences between the central and easternmost regions of Beringia during the late Pleistocene.

In Alaska and Yukon today, A. frigida, bunch-grasses and forb associations are restricted to small, isolated steppe communities on arid, south-facing slopes with well- drained soils, deep active layers and high net insolation ${ }^{9,10}$. Regional full-glacial climatic aridity $^{6}$ provided similar conditions that favoured the widespread establishment of upland steppe flora in eastern Beringia. We conclude that our macrofossils are evidence of the co-occurrence of local steppe vegetation and grazing mammals within the Yukon interior, which characterized the supposed mammoth-steppe ecosystem ${ }^{2}$.

Grant D. Zazula ${ }^{\star}$, Duane G. Froese $\dagger$, Charles E. Schweger $\neq$, Rolf W. Mathewes*, Alwynne B. Beaudoin $\$$, Alice M. Telka |, C. Richard Harington, John A. Westgate\# Departments of ${ }^{\star}$ Biological Sciences and $\dagger$ Earth Sciences, Simon Fraser University, Burnaby, British Columbia V5A 1S6, Canada

e-mail: gdzazula@sfu.ca

\$Department of Anthropology, University of Alberta, Edmonton, Alberta T6G 2H4, Canada $\S$ Provincial Museum of Alberta, Edmonton, Alberta T5N 0M6, Canada

\|PALEOTEC Services, West Ottawa,

Ontario K1R 5K2, Canada

Ganadian Museum of Nature, PO Box 3443, Ottawa, Ontario K1P 6P4, Canada \#Department of Geology, University of Toronto, Toronto, Ontario M5S 3B1, Canada

1. Birks, H. H. \& Birks, H. J. B. J. Biogeogr. 27, 31-35 (2000).

2. Guthrie, R. D. Frozen Fauna of the Mammoth Steppe (Univ. Chicago Press, Chicago, 1990).

3. Cwynar, L. C. \& Ritchie, J. A. Science 208, 1375-1377 (1980).

4. Edwards, M. E. \& Armbruster, W. S. Arc. Alp. Res. 21, 296-304 (1989).

5. Vetter, M. A. Arctic 53, 165-173 (2000).

6. Anderson, P. M. \& Brubaker, L. B. Q. Sci. Rev. 13, 71-92 (1994). Elias, S. A. et al. Nature 382, 60-63 (1996).

8. Goetcheus, V. G. \& Birks, H. H. Q. Sci. Rev. 20, 135-147 (2001). 9. Froese, D. et al. Q. Sci. Rev. 21, 2137-2142 (2002).

10. Harington, C. R. \& Eggleston-Stott, M. Curr. Res. Pleist. 13, 105-106 (1996).

Competing financial interests: declared none 